\title{
Pili of Pseudomonas syringae pathovar syringae enhance initiation of bacterial epiphytic colonization of bean
}

\author{
Anu Suoniemi, $\nmid$ Katarina Björklöf, Kielo Haahtela and \\ Martin Romantschuk
}

\begin{abstract}
Author for correspondence: Martin Romantschuk. Tel: +35804735 415. Fax: +35804735426. e-mail: Romantschuk@cc.Helsinki.Fi
\end{abstract}

Department of General Microbiology, PO Box 41 (Mannerheimintie 172), FIN00014 University of Helsinki, Finland

\begin{abstract}
Pseudomonas syringae pathovar syringae R32 expresses phage- $\phi 6$-specific pili that function as adhesins anchoring bacterial cells to the surface of plants. Phage-resistant piliated and non-piliated mutants were compared to the wildtype strain with regards to pellicle formation and performance during different phases of epiphytic colonization of bush bean. The degree of piliation did not affect the ability of the strains to grow on the undisturbed plant surface. The presence of pili did, however, correlate strongly with the efficiency of the strains to initiate colonization from a liquid inoculation suspension if unadsorbed bacteria were removed by rinsing. During early colonization, wild-type bacteria became virtually resistant to displacement by rinsing within $1 \mathrm{~d}$ after inoculation, whereas non-piliated mutant bacteria became only partly resistant within $3 \mathrm{~d}$. Piliated cells formed a pellicle on the surface of stationary liquid cultures whereas non-piliated mutant strains did not. A mechanism similar to pellicle formation may be functional on the plant surface, explaining in part the difference in resistance to removal by rinsing.
\end{abstract}

Keywords: pilus, attachment, adsorption, bean leaf-surface, Pseudomonas syringae

\section{INTRODUCTION}

Strains of the plant-pathogenic bacterial species Pseudomonas syringae cause disease in specific host plants under suitable conditions. The disease host-range depends on specific pathogenicity and avirulence genes. $P$. syringae strains do, however, also colonize the surface of a wide variety of plants without causing disease symptoms, and the species apparently also contains non-pathogenic strains, or strains for which a disease-susceptible host has not been identified. The epiphytic growth and survival of the bacterium is dependent on general conditions on the leaf surface, and apparently on epiphytic fitness traits of the bacterium. What these traits are has not been investigated in detail, but certain traits, such as desiccation resistance, radiation tolerance, motility, and production of surface active agents, have been suggested (Lindow, 1991). Epiphytic colonization appears not to be host specific. A pathovar that causes symptoms on only its host plant can also colonize the surface of resistant plants or cultivars (Blakeman, 1991; Daub \& Hagedorn, 1981;

† Present address: Institute for Biotechnology, PO Box 45, FIN-00014 University of Helsinki, Finland.
Ercolani et al., 1974; Hirano \& Upper, 1990), although not always at as high population densities (Hirano \& Upper, 1990).

A trait that has been shown to be important for bacterial infection of many animals is the ability to adhere to the host tissue (Jann \& Jann, 1990). In bacteria such as Escherichia coli and Pseudomonas aeruginosa, pilus/fimbriamediated adsorption to the infected tissue is an important virulence factor (Westerlund \& Korhonen, 1993; Doig et al., 1988; Sato et al., 1988). Certain plant-associated bacteria, both symbiotic and pathogenic, have also been shown to adhere to the target tissue. $P$. syringae $\mathrm{pv}$. lacbrymans adheres primarily to veins when cucumber leaves are immersed in a suspension (Leben \& Whitmoyer, 1979), and Agrobacterium adheres to the target plant cell surface (Matthysse, 1983, 1987). Rhizobium leguminosarum biovar viciae was shown to produce an exported protein, rhicadhesin, that mediates the adhesion to root hairs of the host plant (Smit et al., 1989), and Agrobacterium adhesion may also be dependent on this type of protein (Swart et al., 1993).

Various strains of $P$. syringae express pili which function as the primary receptor for the bacteriophage $\phi 6$ (Bamford 
et al., 1976; Vidaver et al., 1973). Mutants exhibiting an altered pilus-expression - either no pilus-expression or an increased number of pili - are obtained by selecting for phage-resistance. It was earlier shown that $P$. syringae pv. phaseolicola HB10Y (HB) adsorbed specifically to the stomata of the host plant, bush bean (Pbaseolus vulgaris), in an in vitro adsorption assay (Romantschuk \& Bamford, 1986). The non-piliated mutant strains adsorbed with a lower efficiency and with no apparent localization, whereas the super-piliated mutants adsorbed with the same distribution as the wild-type but more efficiently. Using spray inoculation followed by a rinsing procedure the piliated strains caused disease symptoms more frequently than the non-piliated mutant, whereas no change in pathogenicity was observed if the bacteria were forced into the leaves (Romantschuk \& Bamford, 1986; M. Romantschuk, unpublished).

P. syringae pv. syringae R32 (R32) causes brown spot disease in bush bean. Unlike strain HB, R32 exhibits no localization of bacterial cells in an adsorption assay, but both wild-type and super-piliated cells are evenly distributed over the leaf surface. The adsorption rate of R32 is higher than that of $\mathrm{HB}$, which may be attributable to the motility of R32 (Romantschuk et al., 1993), but a direct involvement of the flagella as a contributive adhesin has not been ruled out. Mutant strains with altered pilusexpression were isolated as being phage- $\phi 6$-resistant. Lacking the primary phage receptor, the pilus, strain R32.4 does not adsorb phage, and shows a significantly reduced ability to adsorb to bean leaf disks in suspension. As in the case of $\mathrm{HB}$, an R32 super-piliated, $\phi 6$-resistant mutant has also been described (Romantschuk et al., 1993).

Like epiphytic growth, the adsorption of $P$. syringae to plant surfaces appears to be non-host specific. Strains that adsorb efficiently to their respective host plants adsorb efficiently also to the non-host bean (Romantschuk et al., 1993).

Two aspects of bacterial attachment to the surface of plants are described in this work. We explore, on the one hand, the influence of piliation on initiation of plant surface colonization and on the other, the ability of bacteria to resist displacement during ongoing epiphytic colonization.

\section{METHODS}

Bacterial strains, plants and media. $P$. syringae pv. syringae R32 (R32) causes brown spot disease in bean. The wild-type strain is piliated and serves as a host for phage $\phi 6$ (Vidaver et al., 1973). Strain R32.4 is a phage- $\phi 6$-resistant $\left(\phi 6^{\mathrm{R}}\right)$, non-piliated mutant of R32 (Romantschuk et al., 1993). Both mutants are virulent and cause hypersensitivity response in non-host plants. Kanamycin $(\mathrm{Km})$ - and tetracycline (Tc)-resistant transposon mutants of R32 and R32.4 were used in attachment and colonization studies. The transposon mutants made with the Tn 5 derivative transposons B20 and B21 according to Simon et al. (1989) were designated R32:: Km, R32::Tc, R32.4:: Km and R32.4:: Tc.

Bacteria were normally grown overnight in King's medium B
(KB; King et al., 1954) at $28^{\circ} \mathrm{C}$ with shaking. Stationary KB liquid cultures were inoculated with bacteria from overnight shaken cultures and left at room temperature for 1-2 weeks, after which the pellicle-forming capacity of the respective strains was recorded.

Solid media contained $1.5 \%(\mathrm{w} / \mathrm{v})$ agar. Antibiotics were added when appropriate: $\mathrm{Km}\left(25 \mu \mathrm{g} \mathrm{ml}^{-1}\right)$ or $\mathrm{Tc}\left(10 \mu \mathrm{g} \mathrm{ml}^{-1}\right)$. When plating plant-derived material cycloheximide $\left(200 \mu \mathrm{g} \mathrm{ml}^{-1}\right)$ was added to the media.

Bush bean plants (Phaseolus vulgaris cv. Red Mexican) growing in peat moss/vermiculite at low humidity in a growth room were used 10-14 d after potting, when the primary leaves were fully extended.

Inoculation of plants. Bacteria were grown in $\mathrm{KB}$ to late exponential phase, pelleted and resuspended in $10 \mathrm{mM}$ potassium phosphate buffer, $\mathrm{pH} 7 \cdot 2$, and diluted to the desired cell density $\left(10^{6}\right.$ c.f.u. $\mathrm{ml}^{-1}$ unless otherwise stated) in the same buffer or in $0.3 \times \mathrm{M} 9$ salts supplemented with $0.1 \%$ glucose (Romantschuk et al., 1993).

Inoculation of plants was done using two alternative methods. Method I was principally as described by Lindow (1993) with a brief $(30 \mathrm{~s})$ immersion of the foliage of the complete plant in a bacterial suspension in $10 \mathrm{mM}$ potassium phosphate buffer, $\mathrm{pH} 7 \cdot 2$, mixed with a magnetic stirrer. The plants, including all the buffer adhering to the leaves, were then enclosed in plastic bags and incubated at room temperature in a growth room with artificial lighting. The temperature in the bags rose to approximately $30^{\circ} \mathrm{C}$ during the $16 \mathrm{~h}$ daylight period.

Method II was an application of the attachment assay described earlier (Romantschuk et al., 1993). The bean plants were inoculated by immersion of the foliage for $30 \mathrm{~min}$ in a bacterial suspension (in $0.3 \times \mathrm{M} 9$ salts $+0.1 \%$ glucose) that was mixed with a magnetic stirrer, followed by rinsing in the same manner in sterile $10 \mathrm{mM}$ potassium phosphate buffer for $10 \mathrm{~min}$. Incubation of the plants was as with method I. With both methods primary leaves were sampled immediately and at 1, 3 and $5 \mathrm{~d}$ after inoculation.

Quantifying bacteria on the leaves. Enumeration of bacteria was done principally according to Lindow (1993). Six to nine individual leaves were collected per treatment at each sampling time. Leaves were immersed in $10 \mathrm{ml} 100 \mathrm{mM}$ potassium phosphate buffer ( $\mathrm{pH} \mathrm{7.2)} \mathrm{containing} 0.1 \%$ peptone in $18 \mathrm{ml}$ test-tubes. Following a $3 \mathrm{~min}$ sonication in a sonication bath, tubes were vortexed for $10 \mathrm{~s}$ and samples diluted in $10 \mathrm{mM}$ potassium phosphate buffer $(\mathrm{pH} 7 \cdot 2)$ were plated with appropriate selection. This sonication was earlier shown to detach bacterial cells of both piliated and non-piliated strains from the leaf surface with approximately equal efficiency (Romantschuk et al., 1993). Estimates of bacterial population sizes [c.f.u. (g leaf fresh wt $)^{-1}$ ] were $\log _{10}$ transformed to achieve normality (Hirano et al., 1982). Statistical analysis was done using SPSS for Windows.

\section{RESULTS}

\section{Pellicle formation}

Bacterial cells sticking to glass and to each other to form pellicles on the surface of stationary liquid cultures is a phenomenon that has been associated with pili and fimbriae (Goochee et al., 1987; van Doorn et al., 1994). In stationary $5 \mathrm{ml}$ liquid cultures in glass tubes inoculated with $50 \mu \mathrm{l}$ from overnight shaken cultures, the wild-type 


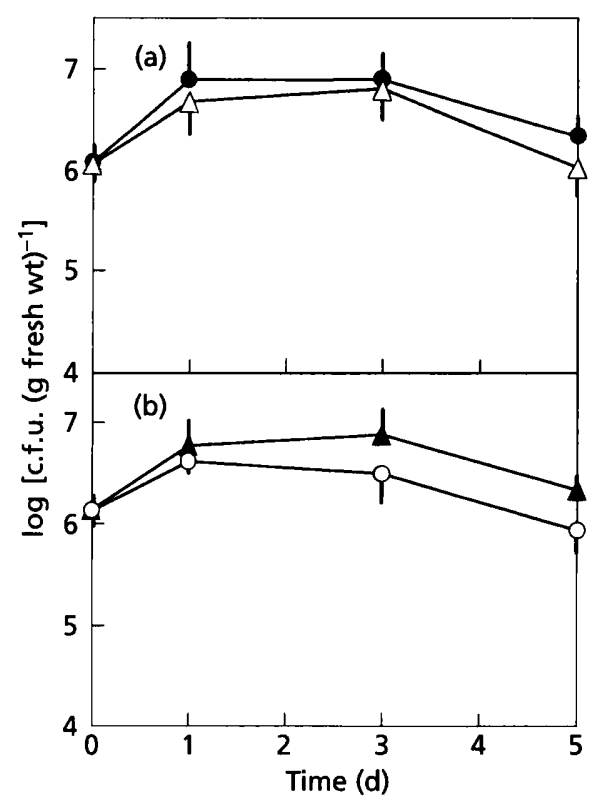

Fig. 1. Growth of mixtures of a piliated and a non-piliated $P$. syringae strain on the surface of bean leaves during a $5 \mathrm{~d}$ incubation period. (a) R32:: $\mathrm{Km}(0)+\mathrm{R} 32.4:: \mathrm{TC}(\triangle)$; (b) R32::TC (O) + R32.4:: Km (A). Inoculation with $1: 1$ mixtures of the strains was done using inoculation method I. The standard deviation of six replicates is indicated by vertical bars.

strain began to form a pellicle within $7 \mathrm{~d}$ of incubation (not shown). By the end of the incubation, the air/liquid interphase of the R32-inoculated tubes was covered with bacterial growth, while the non-piliated strain did not form a pellicle within the $14 \mathrm{~d}$ incubation period, even at higher inoculation levels. No difference in growth rate or final cell density could be observed between the strains in normal shaken cultures or on solid media.

\section{Colonization efficiency measured using brief submersion}

All R32 strains used in this study were tested for epiphytic colonization ability using inoculation method I. Using this method the inoculum level is mainly dependent on the cell-density of bacterial suspension used, and on the volume of suspension transferred to the plant foliage at the submerging procedure, but not on properties of the bacterial cells. This method was thus used to test for changes in the colonization ability of the strains carrying genetic tags, and to test whether the piliation status affects undisturbed epiphytic growth. When the bacterial strains used were inoculated separately, no significant differences in the epiphytic growth pattern or survival were observed (not shown). To obtain an accurate comparison of the wild-type and the non-piliated strain, the assay was performed using 1:1 mixtures $\left(10^{6}\right.$ c.f.u. $\mathrm{ml}^{-1}$ each) of the transposon tagged derivatives of the piliated (R32) and non-piliated (R32.4) strains. Two combinations of bacterial strains were used: $\mathrm{R} 32:: \mathrm{Km}+\mathrm{R} 32.4:: \mathrm{Tc}$, and R32::Tc+R32.4:: Km, respectively (Fig. 1). No

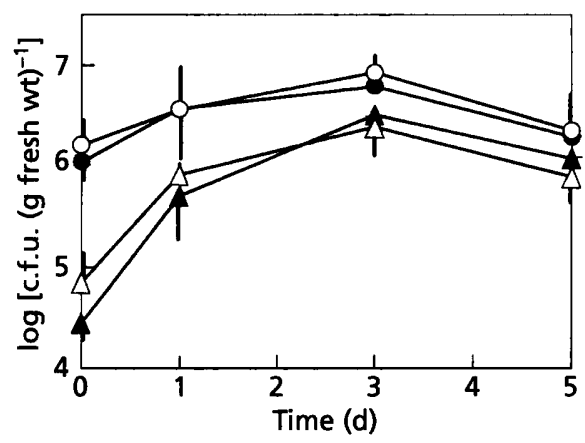

Fig. 2. Population densities of piliated and non-piliated strains during a $\mathbf{5} \mathrm{d}$ incubation period. Inoculation on separate plants for each strain was done with method II (attachment period followed by washing) using bacterial suspensions of identical cell density. The standard deviation of six replicates is indicated by vertical bars. O R32::Tc; O R32::Km; $\triangle$ R32.4::Tc; R32.4:: Km.

differences were observed in the initial population [c.f.u. ( $\mathrm{g}$ leaf fresh $\left.\mathrm{wt})^{-1}\right]$, confirming that the inoculation method is unbiased. After an initial increase, the population density fell back to the inoculation level within $5 \mathrm{~d}$ of incubation. The difference of the population densities between the strains within the $5 \mathrm{~d}$ incubation period remained below $\log 0 \cdot 4$. In both combinations the $\mathrm{Tc}^{\mathrm{R}}$ strains (R32:: Tc, R32.4:: Tc) appeared to stay viable somewhat less efficiently than the $\mathrm{Km}^{\mathrm{R}}$ variants. This may be attributable to the fact that starved cells lose their Tc resistance, and have to be revived before inoculation on selective media, despite the presence of a functional resistance gene (O'Morchoe et al., 1988; Goodman et al., 1993), whereas the $\mathrm{Km}^{\mathrm{R}}$ phenotype is more stable. The final population density of the $\mathrm{Km}^{\mathrm{R}}$ strains (R32:: $\mathrm{Km}$ and $\mathrm{R} 32.4:: \mathrm{Km}$ ) was identical, and the same was true for the $\mathrm{Tc}^{\mathrm{R}}$ strains (R32:: Tc and R32.4:: Tc). It was concluded that the colonization ability of the different strains is unaffected for the purposes of this study. To avoid misinterpretations, however, the following experiments were performed using both combinations (R32:: Km + R32.4::Tc, and R32::Tc + R32.4:: Km), or using only the $\mathrm{Km}^{\mathrm{R}}$ strains.

\section{Colonization after extended attachment period}

The effect of pilus-mediated attachment on colonization initiation was assayed with inoculation method II, comprising a $30 \mathrm{~min}$ attachment period followed by a $10 \mathrm{~min}$ rinsing. The initial bacterial leaf surface population was determined, followed by sampling at different times after the inoculation. Fig. 2 shows the population densities on separately inoculated plants with piliated (R32:: Tc and $\mathrm{R} 32:: \mathrm{Km}$ ) and non-piliated strains (R32.4:: Km and $\mathrm{R} 32.4: \mathrm{Tc}$ ) on bean leaves during the $5 \mathrm{~d}$ incubation period. In all cases the piliated R32 strains showed a significantly higher $(\Delta \log 1 \cdot 1-1 \cdot 6)$ initial population density than the non-piliated R32.4 strains. Within the $5 \mathrm{~d}$ incubation period, the non-piliated strain R32.4 


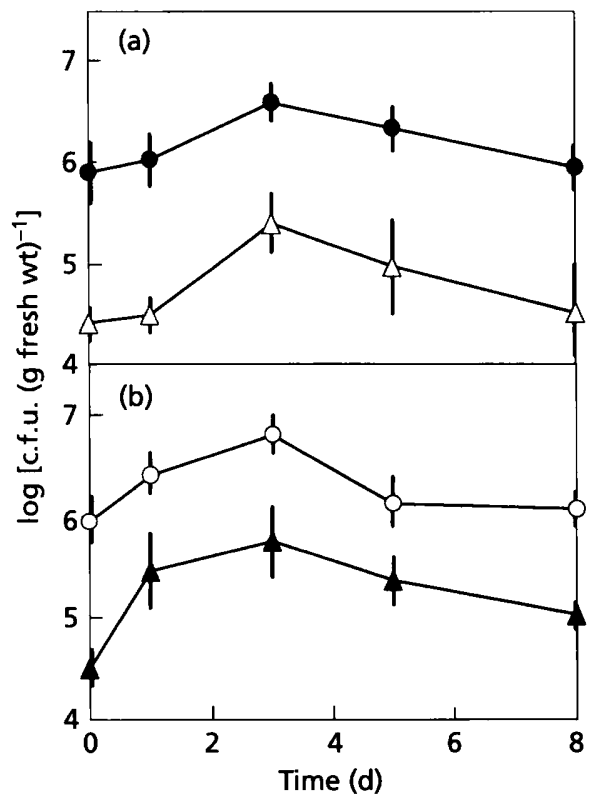

Fig. 3. Epiphytic growth of combinations of a piliated and a non-piliated strain on the same plant after inoculation using method II. (a) R32:: Km (O)+R32.4::Tc ( $\triangle)$; (b) R32::Tc $(\mathrm{O})+\mathbf{R} 32.4: \mathrm{Km}(\mathbf{\Delta})$. The inoculation suspensions were 1:1 mixtures of the strains used in each combination. The standard deviation of six replicates is indicated by vertical bars.

approached the density of the piliated strain despite the lower initial population level using inoculation method II (Fig. 2), confirming that the epiphytic growth of the nonpiliated strains is not impaired once it has started. This apparently reflects the fact that the final epiphytic population density is not dependent on initial inoculum size, in the absence of competition for resources. The plants used were not surface sterilized, but the bacterial population density on the leaves grown at low humidity in the growth room was below $10^{3}$ c.f.u. (g leaf fresh $\mathrm{wt})^{-1}$ (not shown). The resident population is therefore likely to have comprised only a minor portion of the total bacterial population after inoculation with R32.

The relative ability of the wild-type R32 and the nonpiliated strain R32.4 to initiate colonization from a mixed bacterial suspension was compared. Using a 1:1 mixture $\left(10^{6}\right.$ c.f.u. $\mathrm{ml}^{-1}$ each) of piliated and non-piliated bacteria using inoculation method II, an initial bias in favour of the piliated strains was observed (Fig. 3). The ratio of piliated to non-piliated cells was approximately 30:1 immediately after inoculation $(\Delta \log 1 \cdot 5)$, and stayed essentially unchanged throughout incubation. When using the combination $\mathrm{Km}^{\mathrm{R}}$-non-piliated and $\mathrm{Tc}^{\mathrm{R}}$-wildtype (Fig. 3, panel b) there was a statistically significant $(P<0.05)$ change in favour of the non-piliated R32.4 strains between days 0 and 1 and between days 3 and 5 . These small changes may be due to the somewhat unstable $\mathrm{Tc}^{\mathrm{R}}$-phenotype in the conditions used (see above), and are not likely be biologically significant. With the other combination (Fig. 3, panel a) no significant changes in the relative amounts of the bacterial strains was observed. After the $5 \mathrm{~d}$ inoculation period the strains were tested for retained piliation phenotype using phage $\phi 6$ as described earlier (Romantschuk et al., 1993).

In contrast to the experiments with the strains inoculated on separate plants, the strain with the lower initial inoculum (R32.4) was not able to decrease the population density gap to the wild-type R32. The non-piliated strain grows in this situation as part of the total R32 population that during ongoing undisturbed colonization competes for the same nutritional and/or spatial resources. The differential between the strains observed in the competition studies resulted exclusively from a more efficient attachment to the plant surface by the piliated strain during the inoculation procedure whereas the difference in piliation did not affect the relative colonization abilities of the strains on undisturbed plants.

\section{Displacement by rinsing during ongoing colonization}

The role of the pilus-mediated adsorption during ongoing colonization was tested by comparing the ability of the strains to resist displacement by rinsing successively later after inoculation. In this series of experiments the inoculation was done with method I, a brief immersion, to obtain identical initial cell densities and the plants were closed in plastic bags as above. The rinsing was performed as in method II, a $10 \mathrm{~min}$ immersion of the foliage in buffer under mixing. The plants were inoculated with the $\mathrm{Km}^{\mathrm{R}}$ derivatives of $\mathrm{R} 32$ and $\mathrm{R} 32.4$, respectively. With no rinsing the initial bacterial densities per gram fresh leaf weight, $\log 5 \cdot 8$ and $\log 6 \cdot 0$, respectively (Fig. 4), increased by only about $\log 0.6$ in one day, and declined to below $\log 6.0$ by the end of the incubation period. Rinsing immediately after the $30 \mathrm{~s}$ inoculation procedure lowered the wild-type population by $\log 1 \cdot 2(15 \cdot 8$-fold) and the numbers of non-piliated R32.4:: Km cells by $\log 2 \cdot 2$ (158-fold). Rinsing $24 \mathrm{~h}$ after inoculation lowered the R32 level by only $\log 0.3$ (twofold, $P<0.01$ ) compared to the untouched plants, whereas no significant population decrease of R32::Km cells was seen when washing $3 \mathrm{~d}$ after inoculation. For the non-piliated strain R $32 \cdot 4:: \mathrm{Km}$, rinsing at $24 \mathrm{~h}$ post-inoculation lowered the density by $\log 1 \cdot 1$, and rinsing $3 \mathrm{~d}$ after inoculation lowered the density by $\log 0.8$, which both are highly significant population reductions. As above (Fig. 2), the bacterial population on the rinsed plants approached the density of the untouched plant during the continuation of the incubation. The rinsing at day 3 resulted in a somewhat larger population drop from day 3 to day 5 than with the other treatments. With both bacterial strains the relative population reduction was identical within margins of error, and thus not likely to be related to piliation. The effect may instead result from the rinsing procedure removing available nutrients from the leaf surface. At low and increasing population levels (at days 0 and 1 ) this effect would not be distinguishable. At all time points rinsing clearly had less effect on the wild-type R32 (twoway analysis of variance, strain-treatment interaction, 


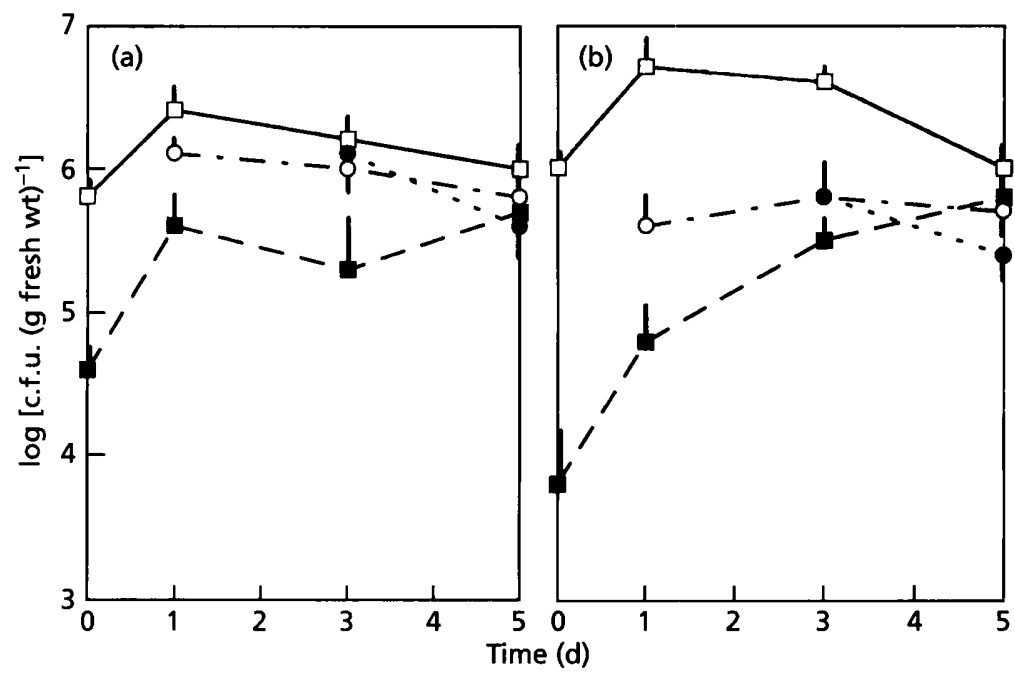

Fig. 4. Measurement of resistance to removal of epiphytically growing bacteria during ongoing colonization. Inoculation was done with method $I$ at day 0 in all cases. The foliage of sampled plants was rinsed at time-points indicated by the start of the respective curve according to the rinsing procedure in inoculation method II. (a) R32:: Km; (b) R32.4::Km. $\square$, No rinsing; $\square$, rinsing immediately following inoculation; $O$, rinsing $1 \mathrm{~d}$ after inoculation; $\boldsymbol{O}$, rinsing $3 \mathrm{~d}$ after inoculation. The standard deviation of six replicates is indicated by vertical bars.
$P \ll 0 \cdot 01$ ), showing the effect of the pilus. The effect of rinsing decreased with increasing incubation time in both cases, however, which suggests that a less efficient alternative means of resistance to displacement is still present in the non-piliated strain.

\section{DISCUSSION}

Epiphytic bacteria are adapted to growing and surviving in the widely varying conditions on the plant surfaces. Bacteria from other habitats can multiply in favourable humid conditions on plant surfaces, but only epiphytes like $P$. syringae survive well in dry conditions (O'Brien \& Lindow, 1988).

Rain, irrigation and dew provide the epiphytic bacteria with the high humidity required for multiplication. Hard rain has been shown to induce much more rapid growth of $P$. syringae than of other epiphytes (Hirano \& Upper, 1992), but at the same time rain and other types of flowing water flush bacteria from the plant surfaces. Thus, a successful epiphyte is probably one that both survives harsh, dry conditions but simultaneously is adapted to maximally proliferate during the transient favourable periods.

Under certain conditions ability to attach gives a selective advantage to a bacterium. The advantage may be manifested both when the bacterial cell arrives at a colonizable surface, as well as during ongoing colonization, as a capacity to resist being displaced. In this study we show that when cells of an epiphytic bacterial strain suspended in a liquid reached the surface of a plant, those cells that were able to attach had a better chance of initiating colonization than the attachment-negative mutant cells.

When the bacteria were used to inoculate plants separately in a manner favouring bacteria that were able to attach, there was a correlation between piliation and initial inoculum on the leaf surface. This initial difference did not, however, affect the level that the bacterial population reached after incubation, which apparently is dependent mainly on availability of nutrients and colonization sites, and on competition from possible other epiphytic colonizers (O’Brien \& Lindow, 1988; Lindow, 1993). When piliated and non-piliated bacteria were inoculated together as mixtures the initial epiphytic cell density of each bacterium was similar to that of the separately inoculated plants. During incubation this ratio in favour of the piliated strain did not change significantly. The non-piliated mutant had to compete for the same resources and thus did not approach the wild-type cell density levels. On the other hand the wild-type strain does not have an advantage over the mutant during undisturbed epiphytic growth. The epiphytic growth per se is thus not dependent on piliation.

Whether a portion of the epiphytic bacterial flora resides in locations on the leaf that are protected from the flushing activity of rain or if the protection is by alternative modes of adherence is not shown by these experiments. What is shown, however, is that the majority of the nonpiliated cells, being unable to attach, can be removed by rinsing after $24 \mathrm{~h}$ and $3 \mathrm{~d}$ of plant surface growth. The wild-type piliated bacterial population, in contrast, becomes relatively insensitive to flushing within $24 \mathrm{~h}$, and this trend is sustained within the following days. A majority of the wild-type bacterial cells colonizing the leaf surface are not suspended in liquid even in the high humidity conditions used, but presumably grow as microcolonies on the solid support that the plant leaf surface provides. Colonization in the form of microcolonies has been observed for e.g. Pseudomonas viridiflava (Mariano \& McCarter, 1993).

Although piliation makes the bacteria relatively insensitive to displacement by running liquid, pilus-mediated adsorption appears not to be the only mode of adsorption during ongoing colonization. The observation that a gradually increasing portion of the non-piliated population becomes resistant to flushing may point to an alternative mode of attachment, linking the cells to the leaf surface as the bacteria grow and microcolonies are formed. This type of interaction may be analogous to the 
secondary attachment of Rbizobium (Smit et al., 1987) to root hairs and Agrobacterium (Matthysse, 1983) to plant wounds (reviewed by Romantschuk, 1992). In interactions following the initial adsorption to the plant surface both bacteria-derived compounds, such as cellulosefibrils, and exopolysaccharides may be important, but in the case of $P$. syringae these phenomena are unexplored.

The capacity of the wild-type R32 strain to form pellicles at air/liquid interphases shows that these piliated bacteria are able to form networks of interlinked cells. The ability of the wild-type strain to resist removal from the plant surface during ongoing colonization more efficiently than the non-piliated strain may in part be a function of their ability to form such networks within microcolonies. Exopolysaccharides are likely to contribute to the material of the pellicle, and may also be of importance on the plant surface (Lindow, 1991), but at least within $3 \mathrm{~d}$ of incubation, this and/or possible additional types of interactions between the bacterial cells and the plant surface do not compensate for the absence of pili.

In conclusion, the data presented suggest that a function of the pilus is to anchor bacterial cells during invasion of new epiphytic surfaces and during early epiphytic colonization to protect them from dislocation by running water - rain or rain-splash and irrigation. Other functions of the pilus, e.g. in plant disease, are not excluded, however.

\section{ACKNOWLEDGEMENTS}

This work was supported by the Maj and Tor NesslingFoundation and by the Academy of Finland. Gunnar Rosenqvist, Reijo Rönkkö, Tore Strandvik, and Risto Väinölä are acknowledged for helpful discussions.

\section{REFERENCES}

Bamford, D. H., Palva, E. T. \& Lounatmaa, K. (1976). Ultrastructure and life cycle of the lipid-containing bacteriophage $\phi 6 . J$ Gen Virol 32, 249-259.

Blakeman, J. P. (1991). Foliar plant pathogens: epiphytic growth and interactions on leaves. J Appl Bacteriol Symp Suppl 70, 49S-59S.

Daub, M. E. \& Hagedorn, D. J. (1981). Epiphytic population of Pseudomonas syringae on susceptible and resistant bean lines. Pbytopathology 71, 547-551.

Doig, P., Todd, T., Sastry, P. A., Lee, K. K., Hodges, R. S., Paranchych, W. \& Irvin, R. T. (1988). Role of pili in adhesion of Pseudomonas aeruginosa to human respiratory epithelial cells. Infect Immun 56, 1641-1646.

van Doorn, J., Boonekamp, P. M. \& Oudega, B. (1994). Partial characterization of fimbriae of Xantbomonas campestris pv. hyacinthi. Mol Plant-Microbe Interact 7, 334-344.

Ercolani, G. L., Hagedorn, D. J., Kelman, A. \& Rand, R. E. (1974). Epiphytic survival of Pseudomonas syringae on hairy vetch in relation to epidemiology of bacterial brown spot of bean in Wisconsin. Phytopathology 64, 1330-1339.

Goochee, C. F., Hatch, R. T. \& Cadman, T. W. (1987). Some observations on the role of type 1 fimbriae in Escherichia coli autoflocculation. In Biotechnology and Bioengineering, vol. XXIX, pp. 1024-1034. New York: Wiley \& Sons.

Goodman, A. E., Hild, E., Marshall, K. C. \& Hermansson, M.
(1993). Conjugative plasmid transfer between bacteria under simulated marine oligotrophic conditions. Appl Environ Microbiol 59, 1035-1040.

Hirano, S. S. \& Upper, C. D. (1990). Population biology and epidemiology of Pseudomonas syringae. Annu Rev Phytopathol 28, 155-177.

Hirano, S. S. \& Upper, C. D. (1992). Population dynamics of Pseudomonas syringae in the phyllosphere. In Pseudomonas: Molecular Biology and Biotechnology, pp. 21-29. Edited by E. Galli, S. Silver \& B. Witholt. Washington, DC: American Society for Microbiology. Hirano, S. S., Nordheim, E. V., Arny, D. C. \& Upper, C. D. (1982). Lognormal distribution of epiphytic bacterial populations on leaf surfaces. Appl Environ Microbiol 44, 695-700.

Jann, K. \& Jann, B. (Eds) (1990). Bacterial adhesins. Current Topics of Microbiology and Immunology, no. 151. Berlin \& Heidelberg: Springer Verlag.

King, E. O., Ward, M. K. \& Raney, D. E. (1954). Two simple media for the demonstration of pyocyanin and fluorescein. J Lab Clin Med 44, 301-307.

Leben, C. \& Whitmoyer, R. E. (1979). Adherence of bacteria to leaves. Can J Microbiol 25, 896-901.

Lindow, S. E. (1991). Determinants of epiphytic fitness in bacteria. In Microbial Ecology of Leaves, pp. 295-315. Edited by J. H. Andrews \& S. S. Hirano. New York: Springer Verlag.

Lindow, S. E. (1993). Novel method for identifying bacterial mutants with reduced epiphytic fitness. Appl Environ Microbiol 59, 1586-1592.

Mariano, R. L. R. \& McCarter, S. M. (1993). Epiphytic survival of Pseudomonas viridiflava on tomato and selected weed species. Microb Ecol 26, 47-58.

Matthysse, A. G. (1983). Role of bacterial cellulose fibrils in Agrobacterium tumefaciens infection. J Bacteriol 154, 906-915.

Matthysse, A. G. (1987). Characterization of non-attaching mutants of Agrobacterium tumefaciens. J Bacteriol 169, 313-323.

O’Brien, R. D. \& Lindow, S. E. (1988). Effect of plant species and environmental conditions on epiphytic population sizes of $P$ seudomonas syringae and other bacteria. Phytopatbology 79, 619-627.

O'Morchoe, S. B., Ogunseitan, O., Sayler, G. S. \& Miller, R. V. (1988). Conjugal transfer of R68.45 and FP5 between Pseudomonas aeruginosa strains in a freshwater environment. Appl Environ Microbiol 54, 1923-1929.

Romantschuk, M. (1992). Attachment of plant pathogenic bacteria to plant surfaces. Annu Rev Pbytopatbol 30, 225-243.

Romantschuk, M. \& Bamford, D. H. (1986). The causal agent of halo blight in bean, Pseudomonas syringae pv. phaseolicola, attaches to stomata via its pili. Microb Patbog 1, 139-148.

Romantschuk, M., Nurmiaho-Lassila, E. L., Roine, E. \& Suoniemi, A. (1993). Pilus-mediated adsorption of Pseudomonas syringae to the surface of host and non-host plant leaves. J Gen Microbiol 139, 2251-2260.

Sato, H., Okinaga, K. \& Saito, H. (1988). Role of pili in the pathogenesis of Pseudomonas burn infection. Microbiol Immunol 32, 131-139.

Simon, R., Quandt, J. \& Klipp, W. (1989). New derivatives of transposon Tn 5 suitable for mobilization of replicons, generation of operon fusions and induction of genes in Gram-negative bacteria. Gene 80, 161-169.

Smit, G., Kijne, J. W. \& Lugtenberg, B. J. J. (1987). Involvement of both cellulose fibrils and $\mathrm{Ca}^{2+}$-dependent adhesin in the attachment of Rbizobium leguminosarum to pea root hair tips. J Bacteriol 169, 4292-4301. 
Smit, G., Logman, T. J. J., Boerrigter, M. T. E. I., Kijne, J. W. \& Lugtenberg, B. J. J. (1989). Purification and partial characterisation of the $\mathrm{Ca}^{2+}$-dependent adhesin from Rhizobium leguminosarum biovar viciae, which mediates the first step in attachment of Rbizobiaceae to plant root hair tips. J Bacteriol 171, 4054-4062.

Swart, S., Smit, G., Lugtenberg, B. J. J. \& Kijne, J. W. (1993).

Restoration of attachment, virulence and nodulation of mutants by rhicadhesin. Mol Microbiol 10, 597-605.

Vidaver, A. K., Koski, R. K. \& Van Etten, J. L. (1973). Bacteriophage
66: a lipid-containing virus of Pseudomonas phaseolicola. J Virol 11, 799-805.

Westerlund, B. \& Korhonen, T. K. (1993). Bacterial proteins binding to the mammalian extracellular matrix. Mol Microbiol 9 , 687-694.

Received 29 July 1994; revised 3 October 1994; accepted 19 October 1994. 